\title{
Experimental and numerical investigation on wave interaction with submerged breakwater
}

\author{
Md. Ataur Rahman, Silwati Al Womera \\ Dept. of Water Resources Engineering, Bangladesh University of Engineering and Technology, Dhaka, Bangladesh
}

\author{
Email address: \\ mataur@wre.buet.ac.bd(Md. A. Rahman)
}

To cite this article:

Md. Ataur Rahman, Silwati Al Womera. Experimental and Numerical Investigation on Wave Interaction with Submerged Breakwater. Journal of Water Resources and Ocean Science. Vol. 2, No. 6, 2013, pp. 155-164. doi: 10.11648/j.wros.20130206.11

\begin{abstract}
Experimental studies are carried out in a two-dimensional wave flume $(21.3 \mathrm{~m}$ long, $0.76 \mathrm{~m}$ wide and $0.74 \mathrm{~m}$ deep) to investigate the performance of rectangular type submerged breakwater. A set of experiments are carried out at $50 \mathrm{~cm}$ still water depth with fixed submerged breakwaters of three different heights $(30 \mathrm{~cm}, 35 \mathrm{~cm}$ and $40 \mathrm{~cm})$ for five different wave periods $(1.5 \mathrm{sec}, 1.6 \mathrm{sec}, 1.7 \mathrm{sec}, 1.8 \mathrm{sec}$ and $2.0 \mathrm{sec})$ in the same wave flume. For fifteen run conditions, water surface elevations are collected at six different locations both in front of and behind the breakwater. Also the type of wave breaking and position of wave breaking are simultaneously recorded with a digital video camera. Effects of breakwater height and length along the wave direction on wave height reduction are analyzed. It is found that both the relative structure height $\left(\mathrm{h}_{\mathrm{s}} / \mathrm{h}\right)$ and relative breakwater width $(\mathrm{B} / \mathrm{L})$ have strong influence in reducing transmitted wave height. Experimental analysis prevails that the reduction of transmitted wave height are $50 \%, 58 \%$ and $68 \%$ for relative structure height $\left(\mathrm{h}_{\mathrm{s}} / \mathrm{h}\right)$ of $0.6,0.7$ and 0.8 respectively, for a particular value of relative breakwater width $(\mathrm{B} / \mathrm{L}=0.35)$. Also, the reduction of transmitted wave height is $32 \%$ and $50 \%$ for relative breakwater width $(\mathrm{B} / \mathrm{L})$ of 0.25 and 0.4 respectively, for a particular value of relative structure height $\left(h_{s} / h=0.6\right)$. A two-dimensional numerical model based on the SOLA-VOF method has been developed in this study to investigate the wave interaction with fixed submerged breakwater. The developed model can simulate time series water surface profiles, water particle velocity field, VOF function F, pressure around a breakwater. The water surface profiles and wave breaking positions in various wave conditions simulated by the developed numerical model show good agreement with the experimentally measured values. The numerical model developed in this study is expected to serve as tool to analyze wave deformation due to submerged breakwater and will be important for designing submerged breakwater as a coastal protection measure.
\end{abstract}

Keywords: Experimental Investigation, Submerged Breakwater, Wave-Structure Interaction, SOLA-VOF

\section{Introduction}

Submerged breakwaters, a special type of breakwaters distinguished from other emerged offshore ones, are built with their crests submerged in the water. With this advantage, they avoid the generation of significant reflected wave that affect the nearby shoreline. Although it might take some disadvantage for navigation, they may be used efficiently as a mean of erosion control as they provide an inexpensive measure of protecting beaches exposed to small or moderate waves and offer fast installation for temporary offshore works. Fixed submerged breakwaters are more effective in reducing wave heights and are also less susceptible to structural failure during catastrophic storms. This nature-conscious coastal protection work has become increasingly popular due to their multiple functions, which are to protect shoreline or harbor and to prevent beach erosion by providing a safe and agreeable environment in coastal areas (Mizutani et al., 1994). This structure scarcely harms the coastal scenery nor obstructs the utilization of sea area; thus, by creating a calm sea, it facilitates the utilization of the sea for recreational and residential developments.

For safety design, many researchers have investigated the interaction between waves and the fixed submerged breakwater experimentally and numerically. Several reports on submerged breakwaters have appeared in the recent past (Rufin et al., 1996; Mizutani et al., 1998; Golshani et al., 2003; Hur et al., 2003), and the state-of-the-art literature review for complete review of the performance characteristics of various types of submerged breakwaters is done (Cheng et al., 2003). Dong-Soo Hur (2004) has investigated the wave deformation of multi-directional 
random waves passing over an impermeable submerged breakwater installed on the slope. The experiments are carried out in the three-dimensional wave basin which is equipped with a multi-directional random wave generator with a segmented wave-maker installing the wooden submerged breakwater on a sloping bed. A study on application analysis of submerged breakwaters to compare the reflection and transmission characteristics with other kinds of breakwaters has been done by Cheng (2003). He has studied the performance of different types of submerged breakwaters both experimentally and numerically.

Al-Banna and Liu (2007) have conducted a numerical study on the hydraulic performance of submerged porous breakwater under solitary wave attack based on solving the Reynolds-Averaged Navier-Stokes (RANS) equations. Lee et al. (2007) have studied the transformation of irregular waves propagating over a submerged breakwater. By providing the incident irregular waves with repeatable amplitude and phase for each wave component, effects of the height and width of the breakwater on the wave transformation have been studied systematically. Hur and
Mizutani (2003) have developed a numerical model, combining the VOF model and porous body model, to estimate the wave forces acting on a three-dimensional body on a submerged breakwater. They have examined wave induced deformation on the permeable submerged structure making use of the porous body model (Sakakiyama and Kajima, 1992) to express the governing equations of fluid motion. Rahman et al. (2006) has developed a two-dimensional numerical model combining the SOLA-VOF model and porous body model, to estimate the wave forces acting on a pontoon type submerged floating breakwater.

In this study, two-dimensional experimental studies are carried out in the laboratory to investigate the performance of submerged breakwater in wave breaking as well as dissipating the incoming wave energy. Also a two-dimensional numerical model based on SOLA-VOF method is developed in this study for simulating wave interaction with submerged breakwater.

\section{Experimental Investigation}

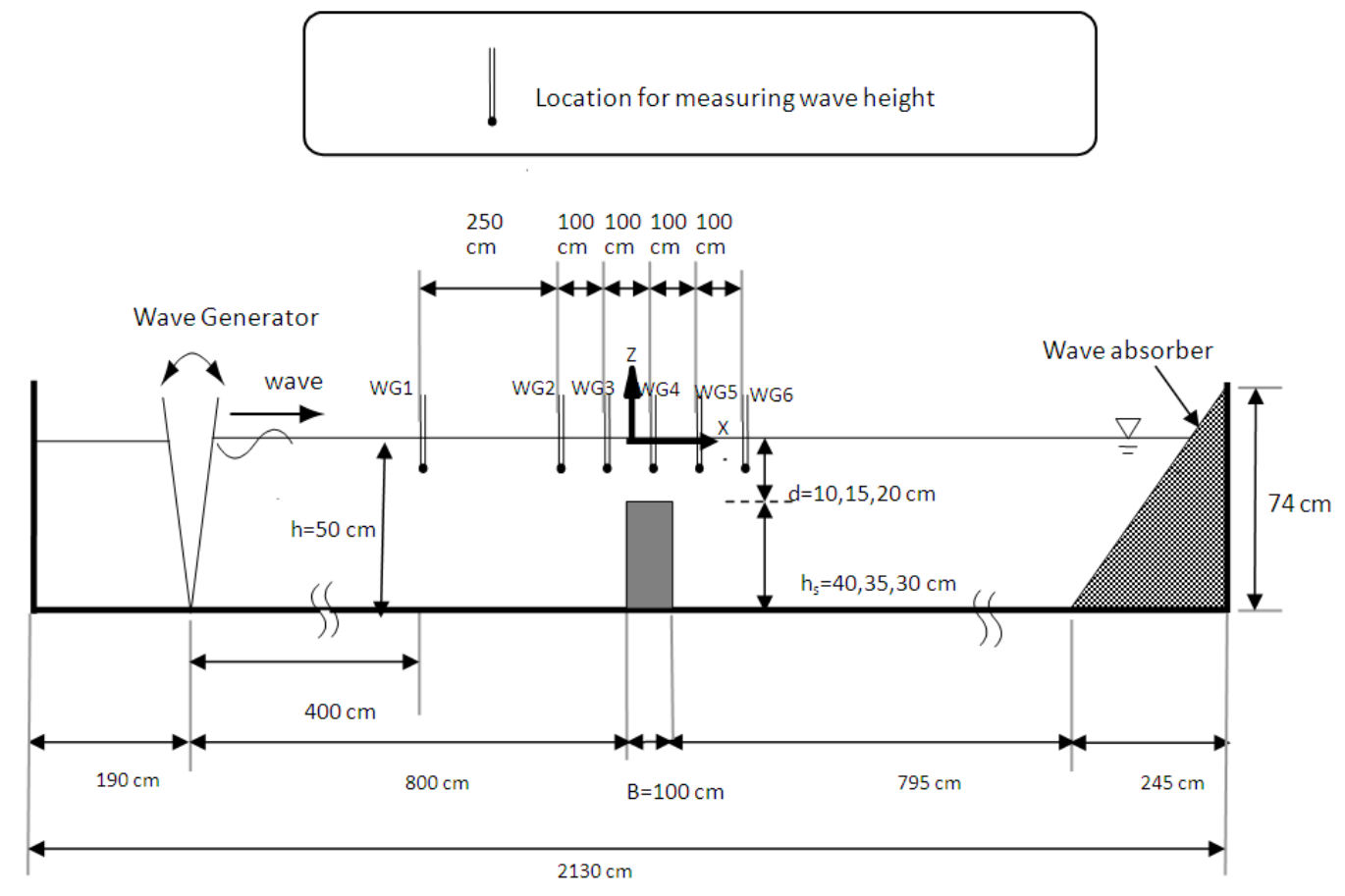

Figure 1. Detail of the experimental setup

To investigate the performance of proposed rectangular type submerged breakwater, experimental studies are carried out in a two-dimensional wave flume (21.3 meters long, 0.76 meter wide and 0.74 meter deep) at the Hydraulics and River Engineering Laboratory of Bangladesh University of Engineering and Technology. Breakwater (length $76 \mathrm{~cm}$, width $100 \mathrm{~cm}$ and three different heights of $30 \mathrm{~cm}, 35 \mathrm{~cm}$ and $40 \mathrm{~cm}$ ) made of cement-sand mixture was installed in at almost middle position of the wave flume containing $50 \mathrm{~cm}$ still water depth. Regular waves with five different wave periods $(\mathrm{T}=1.5 \mathrm{~s}, 1.6 \mathrm{~s}, 1.7 \mathrm{~s}, 1.8 \mathrm{~s}$ and $2.0 \mathrm{~s})$ were generated from a flap type wave generator installed at the upstream end of the wave flume. To damp the transmitted wave after passing the breakwater a wave absorber was installed at the end of the wave flume. For each of fifteen different run conditions, time series water level data were measured at six different positions - three were in front of the breakwater, one was over the breakwater and two positions were behind the breakwater. Moreover, still photographs and video recordings were taken during each run. The detail of experimental setup is shown in Figure 1. 


\section{Numerical Model}

\subsection{Governing Equations}

The free surfaces are modeled with the Volume of Fluid (VOF) technique, which was first reported in Nichols and Hirt (1975), and more completely in Hirt and Nichols (1981). The basic equations used for VOF method are the continuity equation, the Navier-Stokes equation for incompressible fluid and the advection equation that represents the behavior of the free surface. Because the wave generation source is placed within the computational domain, these equations involve the wave generation source. The continuity equation is,

$$
\begin{aligned}
& \frac{\partial u}{\partial x}+\frac{\partial w}{\partial z}=q(x, z, t) \\
& q(x, z, t)=\left\{\begin{array}{l}
q^{*}(z, t) \ldots \ldots \ldots \ldots \ldots \ldots \ldots \\
0 \ldots \ldots \ldots \ldots \ldots \ldots \ldots \ldots \ldots \\
0 \ldots \ldots \ldots \ldots \ldots
\end{array}\right.
\end{aligned}
$$

where $u$ and $w$ are the flow velocity of $x$ and $z$ direction respectively, $q$ is the wave generation source with $q^{*}$ as the source strength which is only located at $x=x_{S}$ and $t$ is the time. The wave generation source $q^{*}$ is defined as follows so that the vertically integrated quantity of $q^{*}$ is equal to that in the non-reflection case (Ohyama and Nadaoka, 1991). $q^{*}$ is also gradually intensified for the three wave periods from the start of wave generation in order to guarantee a stable regular wave train, as mentioned by Brorsen and Larsen (1987), shown in Eq. (3).

$$
q^{*}=\left\{\begin{array}{l}
\left\{1-\exp \left(-\frac{2 t}{T_{i}}\right)\right\} \cdot 2 U_{0} \frac{\eta_{0}+h}{\eta_{0}+h} / \Delta x_{s}: t / T_{i} \leq 3 \\
2 U_{0} \frac{\eta_{0}+h}{\eta_{0}+h} / \Delta x_{s} \\
: t / T_{i}>3
\end{array}\right.
$$

where $t$ is the time from the start of wave generation, $T_{i}$ is the incident wave period, $h$ is the still water depth, and $\eta_{s}$ is the water surface elevation at the source line $\left(x=x_{\mathrm{s}}=0\right) . \Delta x_{s}$ is the mesh size in the $x$-direction at $x=x_{s}$, and is required in order to apply the non-reflective wave generator to the finite difference method. $U_{0}$ and $\eta_{0}$ are the time variation of horizontal velocity and water surface based on third-order Stokes wave theory, respectively. The Navier-Stokes equations are,

$$
\begin{gathered}
\frac{\partial u}{\partial t}+u \frac{\partial u}{\partial x}+w \frac{\partial u}{\partial z}=-\frac{1}{\rho} \frac{\partial p}{\partial x}+v\left(\frac{\partial^{2} u}{\partial x^{2}}+\frac{\partial^{2} u}{\partial z^{2}}\right)+u q \\
\frac{\partial w}{\partial t}+u \frac{\partial w}{\partial x}+w \frac{\partial w}{\partial z}=-\frac{1}{\rho} \frac{\partial p}{\partial z}+v\left(\frac{\partial^{2} w}{\partial x^{2}}+\frac{\partial^{2} w}{\partial z^{2}}\right)+w q+\frac{1}{3} v \frac{\partial q}{\partial z}-g-\beta w
\end{gathered}
$$

where $p$ is the pressure, $v$ is the kinematic viscosity, $\rho$ is the fluid density, $g$ is the gravitational acceleration and $\beta$ is the wave dissipation factor which equals 0 except for the added dissipation zone. The advection equation of VOF function $F$ is derived by considering conservation of mass of the fluid in each cell. The advection equation of VOF function $F$ is,

$$
\frac{\partial F}{\partial t}+\frac{\partial u F}{\partial x}+\frac{\partial w F}{\partial z}=F q
$$

\subsection{Computational Procedure}

\begin{tabular}{|c|c|c|c|c|c|c|c|c|c|c|c|c|c|c|c|}
\hline & & & & & & & & & & & & & & & \\
\hline & $\mathrm{E}$ & $\mathrm{E}$ & $\mathrm{E}$ & $\mathrm{E}$ & $\mathrm{E}$ & $\mathrm{E}$ & $\mathrm{E}$ & $\mathrm{E}$ & $\mathrm{E}$ & $\mathrm{E}$ & $\mathrm{E}$ & $\mathrm{E}$ & $\mathrm{E}$ & $\mathrm{E}$ & \\
\hline & $\mathrm{E}$ & $\mathrm{E}$ & $\mathrm{E}$ & $\mathrm{E}$ & $\mathrm{E}$ & $\mathrm{S}$ & $\mathrm{S}$ & $\mathrm{S}$ & $\mathrm{S}$ & $\mathrm{S}$ & $\mathrm{S}$ & $\mathrm{E}$ & $\mathrm{E}$ & $\mathrm{E}$ & \\
\hline & $\mathrm{S}$ & $\mathrm{E}$ & $\mathrm{E}$ & $\mathrm{E}$ & $\mathrm{E}$ & $\mathrm{S}$ & $\mathrm{F}$ & $\mathrm{F}$ & $\mathrm{F}$ & $\mathrm{F}$ & $\mathrm{S}$ & $\mathrm{S}$ & $\mathrm{S}$ & $\mathrm{S}$ & \\
\hline & $\mathrm{S}$ & $\mathrm{S}$ & $\mathrm{E}$ & $\mathrm{E}$ & $\mathrm{S}$ & $\mathrm{S}$ & $\mathrm{F}$ & $\mathrm{F}$ & $\mathrm{F}$ & $\mathrm{F}$ & $\mathrm{F}$ & $\mathrm{F}$ & $\mathrm{F}$ & $\mathrm{S}$ & \\
\hline & $\mathrm{F}$ & $\mathrm{S}$ & $\mathrm{S}$ & $\mathrm{S}$ & $\mathrm{S}$ & $\mathrm{F}$ & $\mathrm{F}$ & $\mathrm{F}$ & $\mathrm{F}$ & $\mathrm{F}$ & $\mathrm{F}$ & $\mathrm{F}$ & $\mathrm{F}$ & $\mathrm{F}$ & \\
\hline & $\mathrm{F}$ & $\mathrm{F}$ & $\mathrm{F}$ & $\mathrm{F}$ & $\mathrm{F}$ & $\mathrm{OB}$ & $\mathrm{OB}$ & $\mathrm{OB}$ & $\mathrm{F}$ & $\mathrm{F}$ & $\mathrm{F}$ & $\mathrm{F}$ & $\mathrm{F}$ & $\mathrm{F}$ & \\
\hline & $\mathrm{F}$ & $\mathrm{F}$ & $\mathrm{F}$ & $\mathrm{F}$ & $\mathrm{F}$ & $\mathrm{OB}$ & $\mathrm{OB}$ & $\mathrm{OB}$ & $\mathrm{F}$ & $\mathrm{F}$ & $\mathrm{F}$ & $\mathrm{F}$ & $\mathrm{F}$ & $\mathrm{F}$ & \\
\hline & $\mathrm{F}$ & $\mathrm{F}$ & $\mathrm{F}$ & $\mathrm{F}$ & $\mathrm{F}$ & $\mathrm{OB}$ & $\mathrm{OB}$ & $\mathrm{OB}$ & $\mathrm{F}$ & $\mathrm{F}$ & $\mathrm{F}$ & $\mathrm{F}$ & $\mathrm{F}$ & $\mathrm{F}$ & \\
\hline & & & & & & & & & & & & & & \\
\hline
\end{tabular}

$\mathrm{E}=$ Empty cell, $\mathrm{S}=$ Surface cell, $\mathrm{F}=$ Fluid cell, $\mathrm{OB}=$ Obstacle cell

Figure 2. Free surface geometric model of VOF method

The equations (1) to (6) are calculated by a finite difference method using a staggered mesh. The free surface geometric model of VOF method is shown in Figure 2. The grid size of $\Delta \mathrm{x}=2 \mathrm{~cm}$ and $\Delta \mathrm{z}=1 \mathrm{~cm}$ has been used in the model. On the staggered mesh, the flow velocities $u$ and $w$ are put on the cell boundary, and the pressure $p$, wave generation source $q$ and VOF function $F$ are set on the center of each cell. The cell is classified into four types; a full cell filled with fluid, an empty cell occupied by air, a surface cell containing both fluid and air and an obstacle cell that represents the structure. The SOLA scheme is employed to calculate the pressure and flow velocity in each time step. And a type of donor-acceptor flux approximation is used to calculate the advection of the VOF function $F$ computing the free surface. The advections are calculated by velocities of the adjoining cell using a donor cell which transports a fluid 
and an acceptor cell which receives an advect fluid. The physical characteristics of the cell are defined by the values of VOF function $F$. The cell in air, in the surface and in the water are denoted with $F=0,0<F<1$, and $F=1$ respectively.

\subsection{Boundary Conditions}

There are two boundary conditions for water particle velocity, that is, a boundary condition for the velocity parallel to the free-surface and a boundary condition for the velocity normal to the free-surface. In the first boundary condition, the velocity on the surface cell is set equal to the velocity on the interface in contact with the adjacent full cell, which can be calculated by the governing equations. In the second boundary condition, the velocity is determined so that the continuity equation is satisfied in surface cells. An added dissipation zone method (Hinatsu, 1992) is used to treat the open boundaries. The waves are damped by numerical dissipation effects due to the coarse grids and the fictitious damping forces based on the Stokes damping law. Sommerfeld radiation condition is applied for the open boundaries. And, non-slip condition is applied on the sea bed.

\subsection{Calibration of Model}

At first the developed numerical model is run for incident wave period, $\mathrm{T}=0.8 \mathrm{sec}$, incident wave height, $\mathrm{H}_{\mathrm{i}}=4 \mathrm{~cm}$ and still water depth, $\mathrm{h}=40 \mathrm{~cm}$ without any breakwater in the computational domain. The model simulated water surface profiles are compared with the waves generated from Stokes $3^{\text {rd }}$ order wave theory, which shows very good agreement. Then the model is run for five different wave periods ranging from $1.5 \mathrm{sec}$ to $2.0 \mathrm{sec}$ and three different heights of breakwater as $30 \mathrm{~cm}, 35 \mathrm{~cm}$ and $40 \mathrm{~cm}$ to simulate water surface profile, velocity profile, VOF function $\mathrm{F}$ and pressure along the computational domain.

\section{Results and Discussions}

\subsection{Experimental Results}

\subsubsection{Effect of Relative Structure Height on Wave Height Reduction}

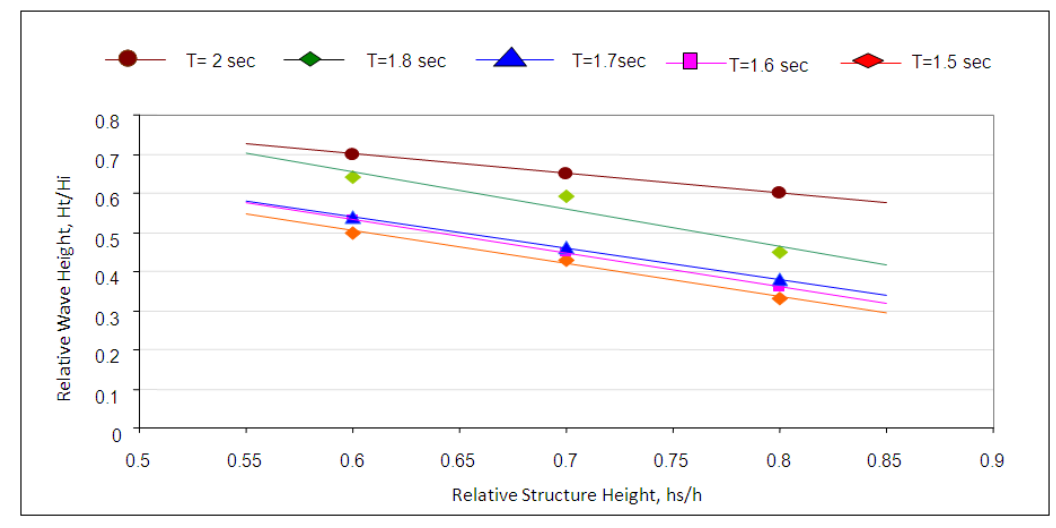

Figure 3. Effect of relative structure height on wave height reduction

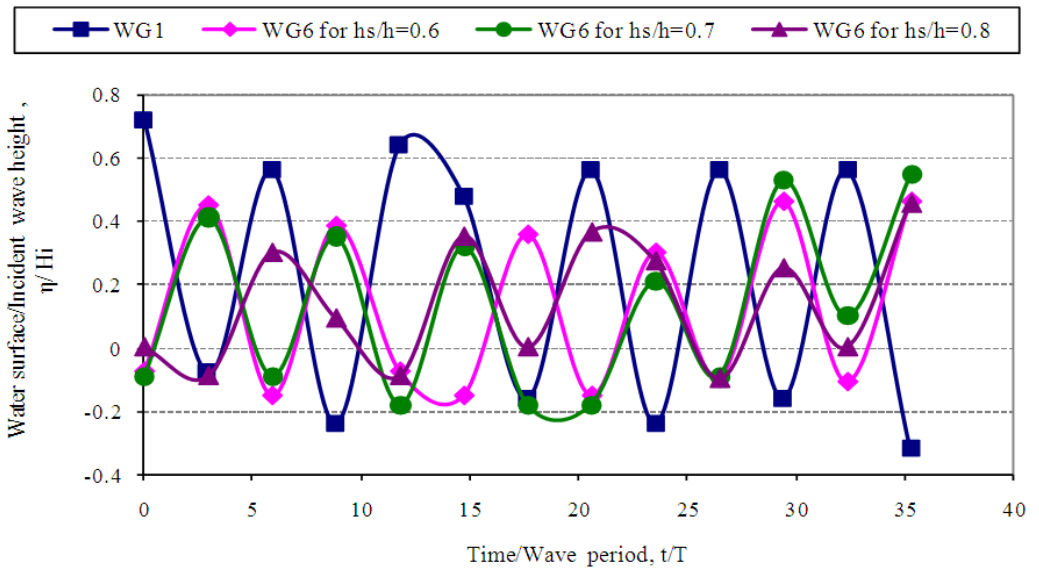

Figure 4. Variation of $\eta / H_{i}$ with $t / T$ for $T=1.7 \mathrm{sec}, H_{i}=13 \mathrm{~cm}$

In Figure 3 the effect of relative structure height, $h_{s} / h\left(h_{s}\right.$ is the height of breakwater and $\mathrm{h}$ is the still water depth) on wave height reduction, $\mathrm{H}_{\mathrm{t}} / \mathrm{H}_{\mathrm{i}}\left(\mathrm{H}_{\mathrm{t}}\right.$ is the transmitted wave height measured at wave gauge 6 and $\mathrm{H}_{\mathrm{i}}$ is the incident wave height measured at wave gauge 1) is shown for five different wave periods. From this figure it prevails that as the relative structure height, $h_{s} / h$ increases, the transmitted wave height, $\mathrm{H}_{\mathrm{t}}$ decreases more with respect to the incident wave height, $\mathrm{H}_{\mathrm{i}}$ for any particular wave period. For wave period $\mathrm{T}=2 \mathrm{sec}$, transmitted wave height reduces about $30 \%$ when $h_{\mathrm{s}} / \mathrm{h}=0.6$. 
For $h_{s} / h=0.7$ and 0.8 , the reduction of transmitted wave height occurs up to $35 \%$ and $40 \%$ respectively. Moreover, for a particular value of $h_{s} / h$, the reduction of transmitted wave height occurs more for lower wave periods than for the higher wave periods. When $\mathrm{h}_{\mathrm{s}} / \mathrm{h}=0.8$, the wave height reduces $40 \%$ and $65 \%$ for $\mathrm{T}=2 \mathrm{sec}$ and $\mathrm{T}=1.5 \mathrm{sec}$ respectively. For $h_{s} / h=0.6$ and 0.7 , the variation of wave height reduction follow the similar trend. The variation of $\eta / H_{i}$ with $t / T$ at wave gauge 1 and wave gauge 6 for different relative structure height is shown in Figure 4. Wave gauge 1 and wave gauge 6 were placed to measure the incident and transmitted wave respectively. In Figure 4 it is seen that the incident wave damps when it passes over the breakwater. Moreover, it prevails from this figure that the wave damping increases with increasing relative structure height (hs/h).

\subsubsection{Effect of Relative Structure Width on Wave Height Reduction}

Figure 5 shows the effect of relative structure width, B/L ( $B$ is the width of breakwater along the wave direction and $\mathrm{L}$ is the wavelength) on wave height reduction, $\mathrm{Ht} / \mathrm{Hi}$ ( $\mathrm{Ht}$ is the transmitted wave height measured at wave gauge 6 and $\mathrm{Hi}$ is the incident wave height measured at wave gauge 1) for three different relative structure heights of $\mathrm{hs} / \mathrm{h}=0.6,0.7$ and 0.8 . For a particular relative structure height, it is seen that as $\mathrm{B} / \mathrm{L}$ increases, the reduction of transmitted wave height also increases.

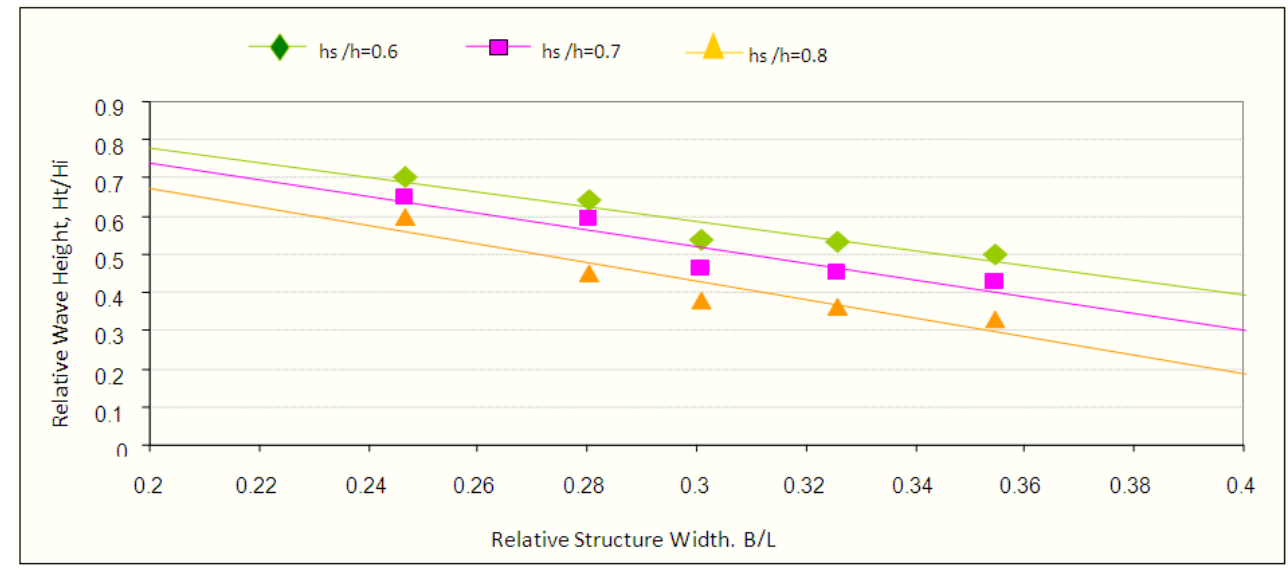

Figure 5. Effect of relative structure width on wave height reduction

For $\mathrm{hs} / \mathrm{h}=0.6$ and $\mathrm{B} / \mathrm{L}=0.25$, reduction of transmitted wave height is $32 \%$, whereas for the same breakwater height, wave height reduces $50 \%$ as the relative structure width, $\mathrm{B} / \mathrm{L}$ becomes 0.35 . The scenario is similar for $\mathrm{hs} / \mathrm{h}=0.7$ and 0.8 . Again for a particular value of $\mathrm{B} / \mathrm{L}$, the transmitted wave height, Ht decreases more with respect to the incident wave height $\mathrm{Hi}$ for higher value of hs/h. When the ratio of relative structure width, $\mathrm{B} / \mathrm{L}$ is 0.2 , wave height is reduced to $32 \%$, $27 \%$ and $22 \%$ for $\mathrm{hs} / \mathrm{h}=0.6,0.7$ and 0.8 respectively. For any value of $\mathrm{B} / \mathrm{L}$ the trend is almost similar. But as discussed earlier, when breakwater width increases, the reduction of wave height occurs more for any value of hs/h.

\subsubsection{Wave Breaking}

From the still photographs and video recording data during each experimental run, the positions of wave breaking are analyzed. Wave breaking over and behind the breakwater during two experimental runs are shown in Figure 6.
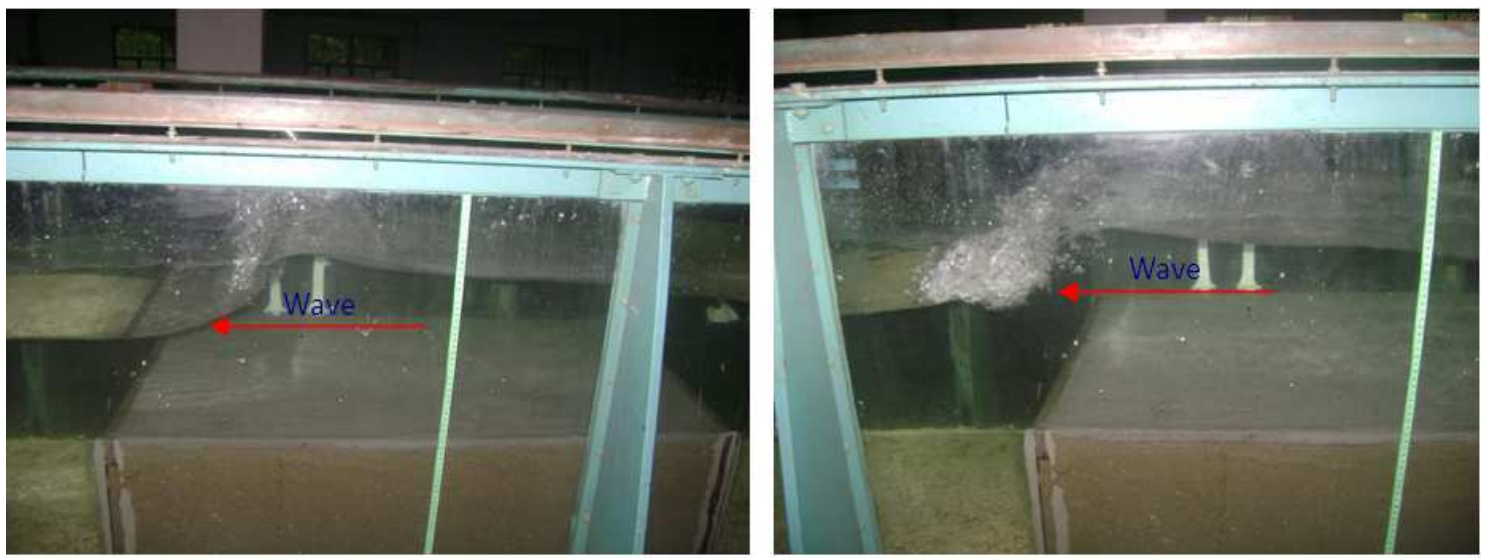

Figure 6. Wave breaking over the breakwater 


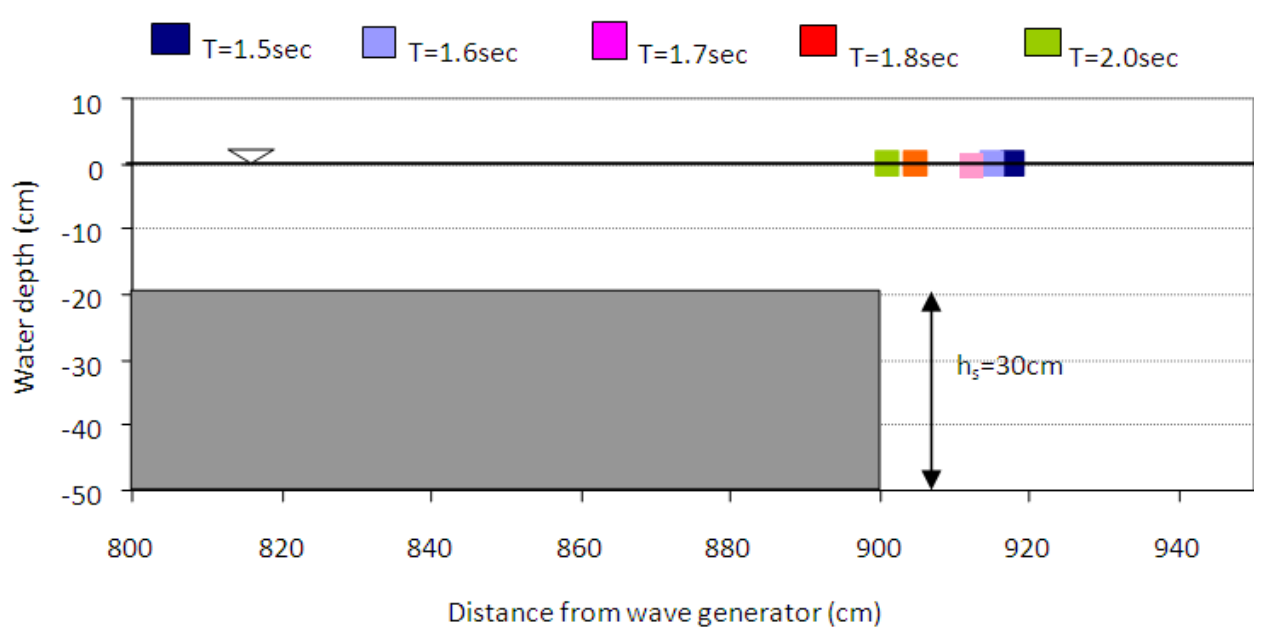

Figure 7. Position of wave breaking for $30 \mathrm{~cm}$ height of breakwater

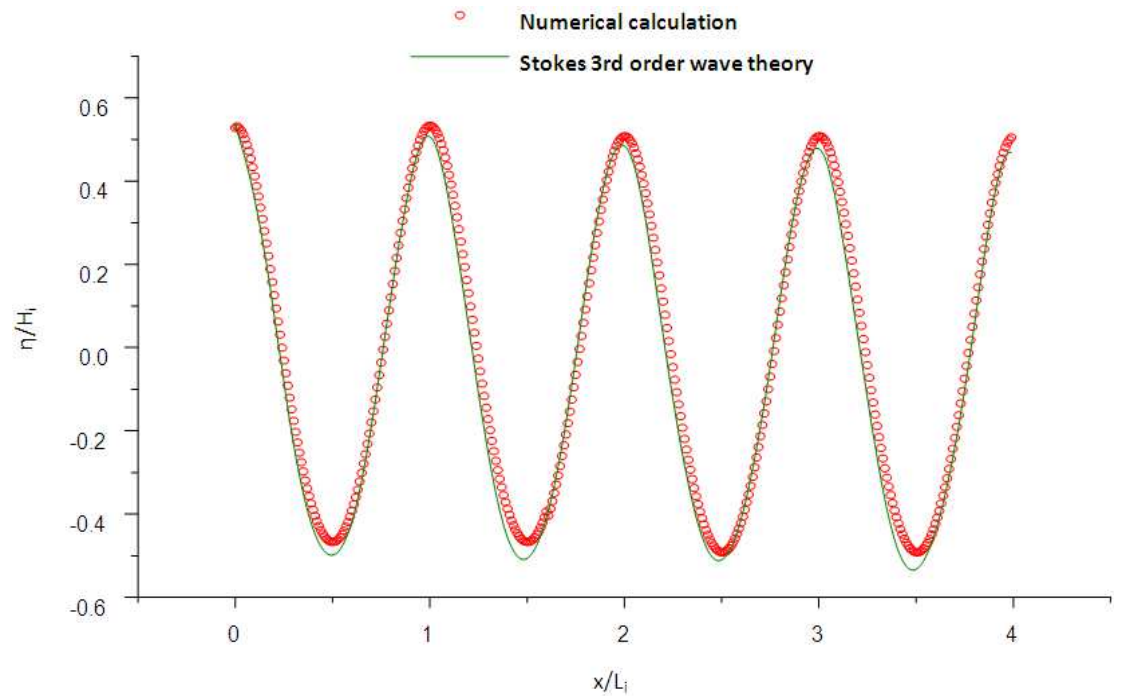

Figure 8. Comparison of numerical and $3^{\text {rd }}$-order Stokes wave theory results of dimensionless water surface profiles $\left(H_{i}=4 \mathrm{~cm}, T=0.8 \mathrm{sec}, \mathrm{h}=40 \mathrm{~cm}\right)$

Figure 7 shows the position of wave breaking behind the breakwater for breakwater height hs $=30 \mathrm{~cm}$. The breaking positions are seen just behind the breakwater. For $35 \mathrm{~cm}$ and $40 \mathrm{~cm}$ height of breakwater the breaking positions are seen at the onshore and at the middle position over the breakwater respectively. For a particular height of breakwater, as the wave height increases, the breaking position comes toward the offshore side. For $\mathrm{hs} / \mathrm{h}=0.6$, the variation of wave breaking positions are within $20 \mathrm{~cm}$ behind the breakwater for all wave periods. For the same wave periods, breakwater having $\mathrm{hs} / \mathrm{h}=0.7$ and 0.8 wave breaks with $25 \mathrm{~cm}$ and $15 \mathrm{~cm}$ variation in length over the breakwater respectively. Moreover, when the breakwater height increases keeping the same still water depth, the waves tend to break more quickly than that for lower height of breakwater.

\subsubsection{Performance of the Submerged Breakwater}

Analysis of laboratory experimental data reveals that both the height and width of the submerged breakwater has strong influence in reducing the wave height propagating over the breakwater and transmitted to the shore. As energy of wave is direct propotional to the square of the wave height $(\mathrm{E} \propto$ $\mathrm{H}^{2}$ ), so damping of incident ocean wave height of $50 \%$, when it propagates over the breakwater, results $75 \%$ dissipation of wave energy trasmitted to the shore. This performance of the submerged breakwater makes it very effective in beach restoration project. It is revealed from Figure 5 that the breakwater having height of $70 \%$ of the water depth $\left(h_{s} / h=0.7\right)$ and width of $30 \%$ of incident wave length $(\mathrm{B} / \mathrm{L}=0.3)$ damps $50 \%$ of wave height.

It should be mentioned that the emerged breakwaters are designed to attenuate the whole wave action and are submitted to the direct impact of wave breaking, resulting in larger structures that often eliminate water circulation at the lee side (in the protected area). Consequently degradation of water quality and of natural habitats in the lee-side is a frequent phenomenon. The environmental result is obviously not highly appreciated, due to its big visual impact, together with the strong erosion phenomena noticed at the gaps between barriers. On the other hand, in submerged breakwaters, as these structures are constructed below a specified design water level, some overtopping is permitted, 
allowing he circulation along the shoreline zone. The submerged breakwaters have a height of $50-70 \%$ of the water depth may permit sufficient water exchange preserving the healthiness and the bathing use of the water in the protected area and resulting an environment-friendly, natural and low price stable beach.

\subsection{Numerical Model Results}

The developed numerical model is verified first by comparing the simulated water surface profile with that should be as Stokes $3^{\text {rd }}$ order wave theory. In Figure 8, it is seen that the dimensionless water surface profile by the developed model show very good agreement with that of the Stokes $3^{\text {rd }}$ order wave theory.

\subsubsection{Simulation of Water Surface and Velocity Profiles}

Figure 9 shows the numerical simulation of water surface profiles along the channel length and the water particle velocity field around the breakwater. The wave height, the wave period and the water depth are considered as $15 \mathrm{~cm}$, 2.0 seconds and $50 \mathrm{~cm}$ respectively. Rectangular fixed submerged breakwater of two different heights as $20 \mathrm{~cm}$, and $40 \mathrm{~cm}$ are considered here for the numerical model simulation. For $20 \mathrm{~cm}$ high breakwater no wave breaking occurs and no disturbance is seen in the water surface profiles as well as in velocity field. When $40 \mathrm{~cm}$ breakwater is installed, the wave breaks over the breakwater and water particle velocity abruptly changes due to breaking.
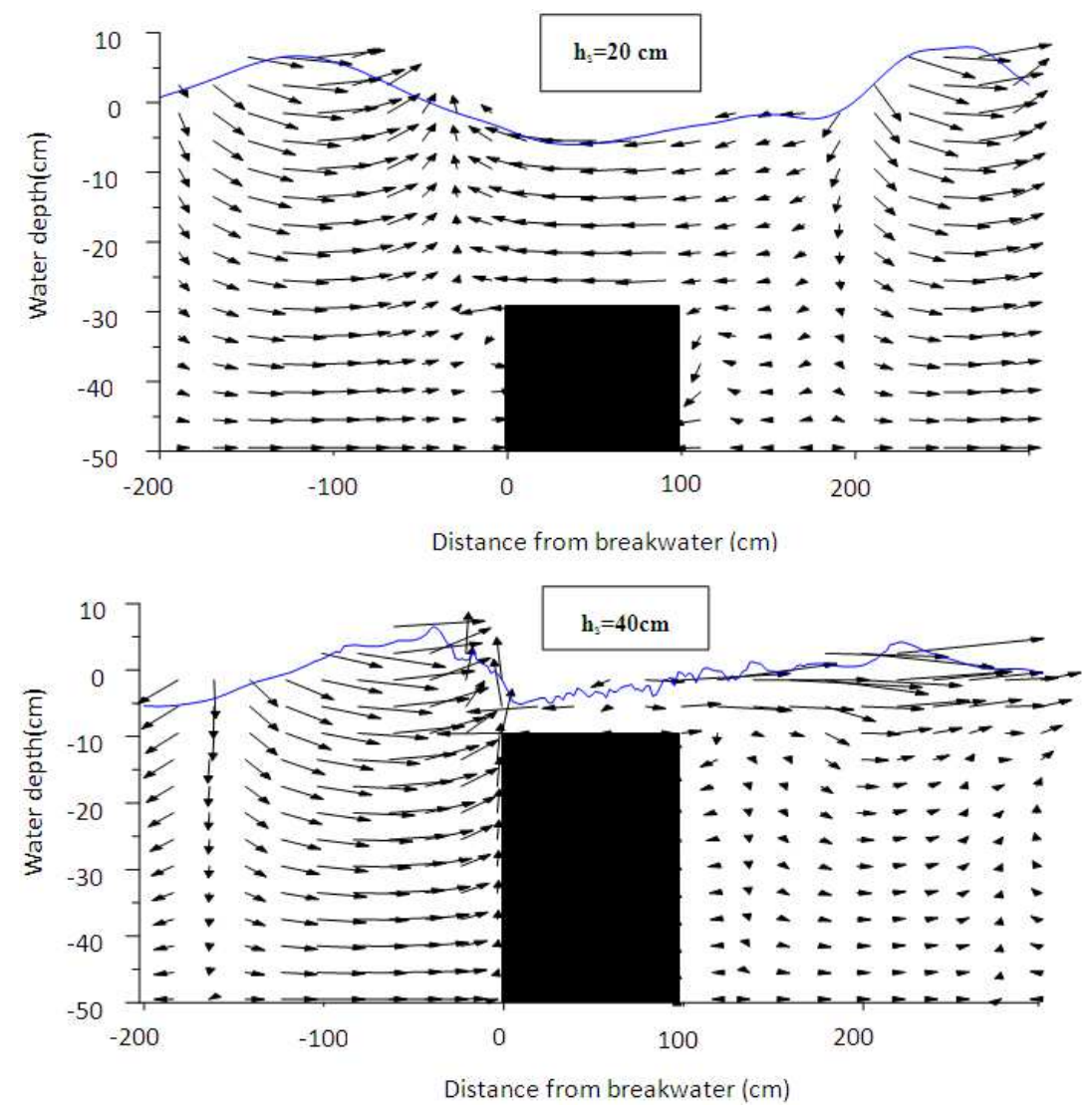

Figure 9. Numerical model simulation of water surface profile and velocity profile for both breaking and non-breaking condition $\left(H_{i}=15 \mathrm{~cm}, T=1.5 \mathrm{sec}\right.$, $h=50 \mathrm{~cm}$ )

\subsubsection{VOF function F around the Breakwater}

Figure 10 shows the numerical simulation of the contour map of the VOF function $\mathrm{F}$, which ranges from 0 to 1 at 15 sec after starting the simulation. The wave height, wave period and the water depth are considered as $10 \mathrm{~cm}, 1.5$ seconds and $50 \mathrm{~cm}$ respectively.

The solid portion in the middle of this figure represents the breakwater containing the obstacle cell having $\mathrm{F}=0$. The deep gray color around the breakwater represents the water containing the fluid cells having $F=1$. The $F$ value of the top surface of the water surface profile is seen less than $1(\mathrm{~F}<1)$, that represents the surface cells. On the right side of the top surface of the breakwater, it is seen that the wave front becomes light gray color having $\mathrm{F}<1$. It prevails that the breaking of wave occurs here and the air-bubble entrained in the corresponding numerical mesh cells due to wave breaking reduces the water volume less than the full volume of a fluid cell. For this reason the numerical model calculates $\mathrm{F}$ value of these cells less than 1. Also, the cells having $\mathrm{F}<1$ are seen in both offshore and onshore side of the breakwater. This may happen due to the reason that the higher water particle velocity in vertically downward direction may cause partial void at some cells near the bottom forming vortex in this zone. 


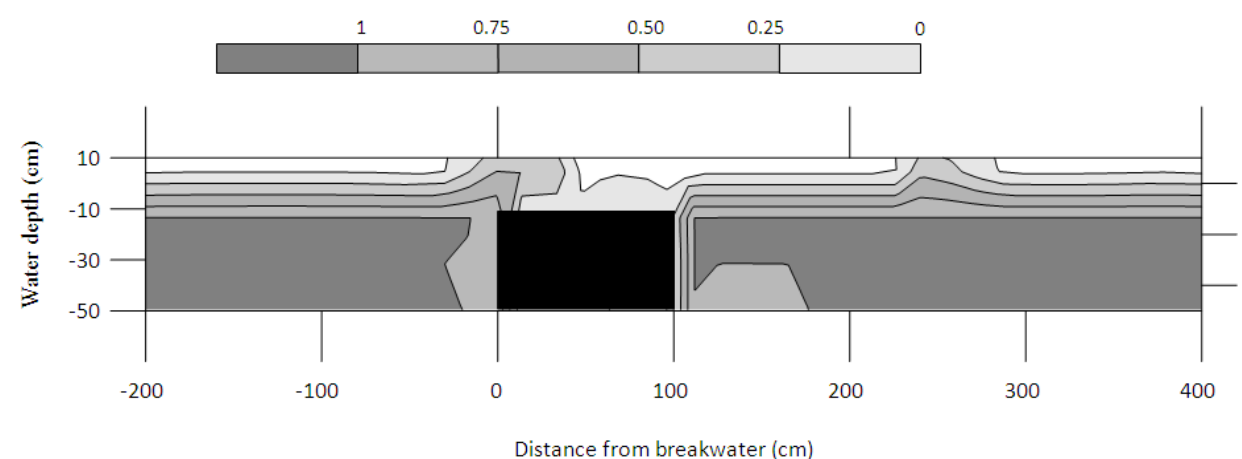

Figure 10. Numerical model results of contour map VOF function value F around the submerged body with height $40 \mathrm{~cm}(H=10 \mathrm{~cm}, T=1.5 \mathrm{sec}, \mathrm{h}=50 \mathrm{~cm})$
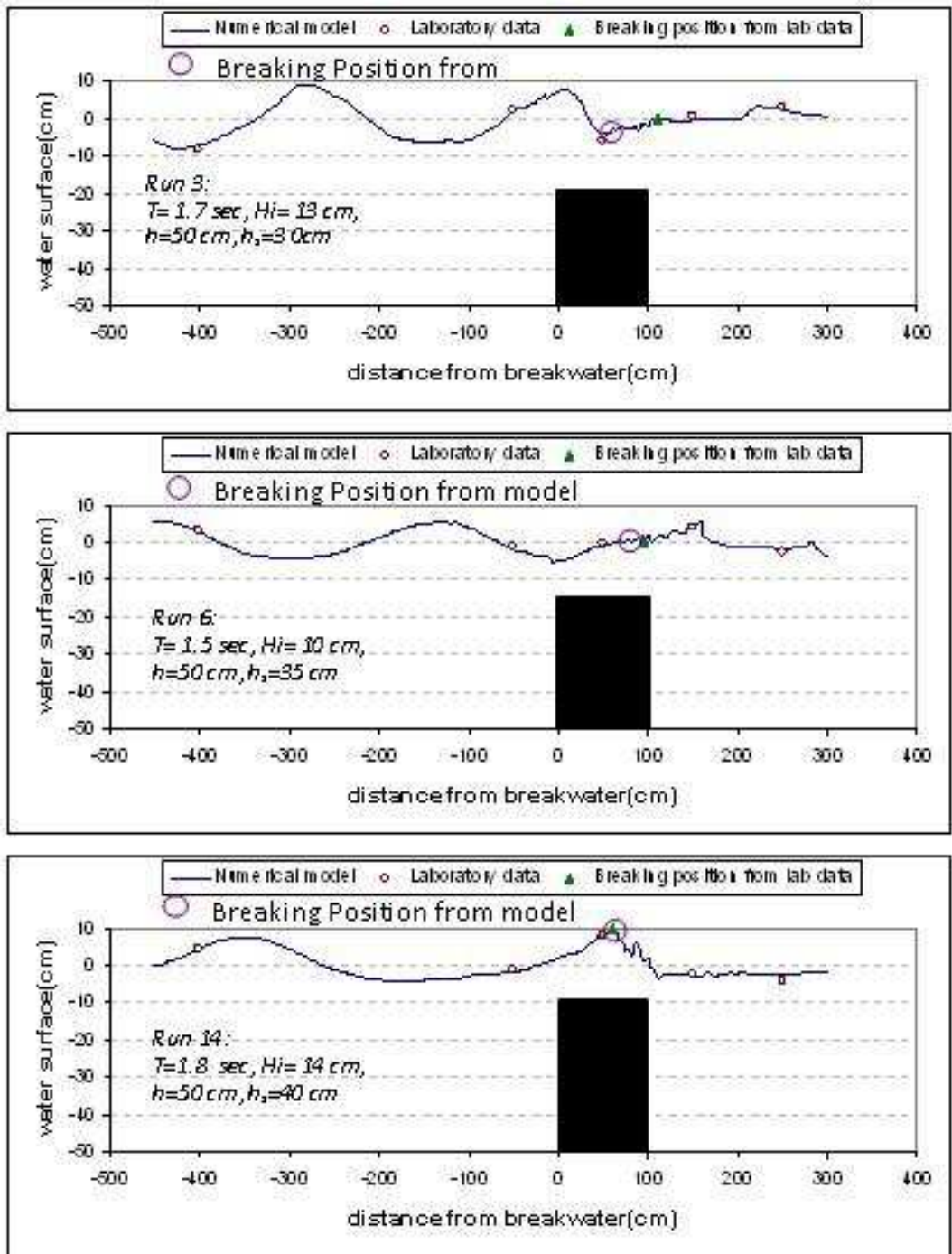

Figure 11. Comparison between numerical and experimental results of water surface profiles and breaking position

\subsection{Comparison between Numerical and Experimental Results}

The performance of the developed two-dimensional numerical model has been verified by comparing the model simulated results with experimentally measured data. The model simulated water surface profiles for three laboratory run conditions (Run No. 3, 6 and 14) are compared with the experimentally measured data for the respective run conditions and are shown in Figure 11. From the figure it is seen that the developed numerical model can track the free surface of the passing wave very well with little error less than $5 \%$. It can track the free surface of the passing wave not only before interaction with the breakwater, but also during 
breaking due the interaction with breakwater and also during transmitted to the shore. Wave breaking positions measured during Run No. 3, 6 and 14 of the laboratory experiments are also shown in this figure with triangular symbol to compare with the locations of wave breaking simulated by the numerical model marked with the larger circles. In the model simulated water surface profiles the breaking position is considered at the point where the wave collapses. In Run No. 3, model simulated wave breaking position differs 55 $\mathrm{cm}$ from that of the laboratory measured data, which makes an error of $12 \%$ with respect to wave length of that wave. In Run No. 6 , this difference is $8 \mathrm{~cm}$, which makes an error of less than $3 \%$ with respect to wave length of that wave. In Run No. 14, it is seen that the numerical model simulates the exact position of the wave breaking position as of laboratory data with no error.

\section{Conclusion}

Submerged breakwater is a nature-conscious coastal protection work that prevents beach erosion and provides a safe and agreeable environment in the coastal areas. In this research work, the interaction between wave and rectangular fixed submerged breakwater has been investigated both experimentally and numerically to find out the effective size of this protection structure for the reduction of wave height. In a two-dimensional wave flume, fifteen experimental runs have been conducted with solid submerged body of three different structure heights $\left(\mathrm{h}_{\mathrm{s}}=30 \mathrm{~cm}, 35 \mathrm{~cm}\right.$ and $\left.40 \mathrm{~cm}\right)$ in fixed still water depth $\mathrm{h}=50 \mathrm{~cm}$ for five different wave periods as $\mathrm{T}=1.5 \mathrm{sec}, 1.6 \mathrm{sec}, 1.7 \mathrm{sec}, 1.8 \mathrm{sec}$ and $2.0 \mathrm{sec}$. Moreover, a two-dimensional numerical model using SOLA-VOF is proposed in this study to simulate the wave interaction with fixed rectangular shaped submerged breakwater. The model can simulate water surface profile, velocity profile, water pressure all through the flume length including wave breaking over and around the breakwater. The experimentally measured water surface profiles and wave breaking positions are compared with the model simulated results. The key findings from this study are as follows.

(i) From the experimental investigations, it is seen that for any particular wave period the relative structure height $\left(\mathrm{h}_{\mathrm{s}} / \mathrm{h}\right)$ and the relative structure width $(\mathrm{B} / \mathrm{L})$ are the important parameters for damping the wave height passing over the breakwater. Increase of relative structure height $\left(h_{s} / h\right)$ for a particular value of relative breakwater width $(\mathrm{B} / \mathrm{L})$ or increase of relative breakwater width $(\mathrm{B} / \mathrm{L})$ for a particular value of relative structure height $\left(h_{s} / h\right)$, both can damp the incoming wave height to a significant level, which plays an important role in controlling the beach erosion and restoring the beaches. Considering the disadvantages of emerged breakwater resulting degradation of water quality and of natural habitats in the lee-side, this study suggests submerged breakwater having height of $70 \%$ of the water depth $\left(h_{s} / h=0.7\right)$ and width of $30 \%$ of incident wave length $(\mathrm{B} / \mathrm{L}=0.3)$ which can damp $50 \%$ of wave height passing over the breakwater and transmitted to the shore. It results $75 \%$ dissipation of wave energy trasmitted to the shore and also permit sufficient water exchange over the breakwater preserving the healthiness and the bathing use of the water in the protected area and resulting an environment-friendly, natural and low price stable beach.

(ii) The numerical model developed in this study can simulate water surface profiles, water particle velocity field, wave breaking positions, dynamic water pressure due to interaction between the wave and submerged breakwater. Comparison of model simulated water surface profiles with that of laboratory measured data shows very good agreement with little error less than $5 \%$. Moreover, the developed numerical model can simulate the wave breaking positions resulting from wave-structure interaction with error limit up to $12 \%$. Hence the developed numerical model can be used for interaction of submerged breakwater of any height and width exposed to various wave conditions. The developed model can help the coastal engineers to fix the position and to select the dimension during design of submerged breakwater under various wave conditions.

\section{References}

[1] Al-Banna, K. and Liu, P. (2007). "Numerical study on the hydraulic performance of submerged porous breakwater under solitary wave attack". Journal of Coastal Research, Vol. 50, pp. 201-205.

[2] Brorsen, M and Larsen, J. (1987) "Source generation of nonlinear gravity waves with the boundary integral equation method," Coastal Engineering, Elsevier, Vol. 11, Amsterdam, pp. 93-113.

[3] Cheng, S., Liu, S. and Zheng, Y. (2003) "Application Study on Submerged Breakwaters used for Coastal Protection," Proceedings of International Conference on Estuaries and Coasts, China.

[4] Golshani. A., Mizutani. N and Hur. D. S. (2003) "Three-dimensional Analysis of Non-linear Interaction between water waves and Vertical Permeable Breakwater", Journal of Coastal Engineering, World Sientific, Vol. 45, pp. 329-3451-28.

[5] Hinatsu, M. (1992). "Numerical simulation of unsteady viscous non-linear waves using moving grid system fitted on a free surface.” J. Kansai Soc. Naval Arch. Japan 217: 1-11.

[6] Hirt, C.W. and Nichols, B.D. (1981). "Volume of fluid (VOF) method for the dynamics of free boundaries," J. Comp. Physics, Vol. 39, pp. 201-225.

[7] Hur, D.S. (2004). "Deformation of Multi-directional Random waves passing over an impermeable Submerged Breakwater installed on Sloping bed", Journal of Ocean Engineering, Elsevier, Vol. 31, pp. 1295-1311. 
[8] Hur, D.S. and Mizutani, N. (2003). "Numerical estimation of wave forces acting on a three-dimensional body on submerged breakwater", Journal of Coastal Engineering, Elsevier, Vol. 47, pp. 329-345.

[9] Hur, D.S., Kawashima. N. and Iwata. K. (2003). "Experimental study of the Breaking Limit of Multi-directional Random waves passing over an Impermeable Submerged Breakwater", Journal of Ocean Engineering, Sciencedirect, Vol. 30, pp. 1923-1940.

[10] Lee, C., Shen, M. and Huang, C. (2007). "Transformation of irregular waves propagating over a submerged breakwater", Proceedings of the 12th ISOPE Conference.

[11] Mizutani, N., Rufin, T.F. and Iwata, K. (1994), "Stability of Armor Stones of a Submerged Wide-Crown Breakwater", Proceedings of the 24th International Conference Coastal Engineering, Kobe-Japan, 1994, pp 1439-1453.

[12] Mizutani. M, Mostafa, A. M. and Iwata, K. (1998). "Non-linear Regular wave, Submerged Breakwater and Seabed Dynamic Interaction", Journal of Coastal Engineering, Elsevier, Vol. 33, pp. 177-202.
[13] Nichols, B.D. and Hirt, C.W. (1975), "Methods for Calculating Multidimensional, Transient Free Surface Flows Past Bodies", Proc. of the First International Conf. On Num. Ship Hydrodynamics, Gaithersburg, ML.

[14] Ohyama, T. and Nadaoka, K. (1991). "Development of a numerical wave tank for analysis of nonlinear and irregular wave field." Fluid Dynamics Research 8: 231-251

[15] Rahman, M.A., Mizutani, N. and Kawasaki, K. (2006). "Numerical modeling of dynamic responses and mooring forces of submerged floating breakwater", Journal of Coastal Engineering, Elsevier, Vol. 53, pp. 799-815.

[16] Rufin, T.M., Mizutani. N. and Iwata. K. (1996) "Estimation method of Stable Weight of Spherical Armor unit of a Submerged Wide-crown Breakwater", Journal of Coastal Engineering, Elsevier, Vol. 28, pp. 183-228.

[17] Sakakiyama, T. R. and Kajima, R. (1992). "Numerical simulation of nonlinear wave interacting with permeable breakwaters," Proc. 22nd Int. Conference on Coastal Engineering, ASCE, Venice, pp. 1517-1530. 